\section{Respecting a Korean health custom in a western society}

\author{
Robin L. Cooper \\ Department of Biology, BSN student \\ in College of Nursing, University \\ of Kentucky, Lexington, KY, USA
}

It is a challenge to accept oddities to one's own training and customs when in community clinics but as nurses we are trained to assess the value and impact of cultural differences in care by patients and their families. If no harm or mental discomfort will result from a séance or an ointment of religious significance applied to the forehead we go about our business and welcome patients to do as they see fit, according to their own culture and belief system. But how about if someone is applying a traditional cultural healing originating from your own culture to your own child which results in breaking the skin and results in bleeding?

This is a personal story which I realized could be of value to nurses in general. Though highlighting subtleties in cultural differences in health care, via case reports, we can be more aware of transcultural procedures in health care. Awareness before an incident helps health care providers to keep an open mind in the clinics or with home health care when treating clients with diverse cultural backgrounds.

My own children were sick with some form of indigestion (i.e., Beck A Pho in Korean) and I knew coming home would be an evaluation of how they were doing for the day, but in addition my mother-in-law arrived from Seoul, Korea. Well, the in-law and I get along well as I don't speak Korean and she does not speak much English. So there is never a debate in which we understand each other. But today my wife was a busy translating to explain why the kids are saying Grandma made them bleed and took the bad blood away. Thoughts were going through my head of the French physicians in the 1700's who used leeches to cure all kinds of aliments. ${ }^{1}$ Leeches are used in Western medicine for maintaining blood flow to tissue surgically replaced or transplanted, such as an ear or a digit, ${ }^{2}$ but not for general systemic health matters. The kids are showing me the small pricks in their skin right between the nail bed and the distal joint on their thumbs.

The curing process of removing the bad blood responsible for the kid's colds starts off by massaging the feet and working the massage up the legs to the thighs and over the chest to be followed with massaging the arms to push the blood into the hand. The whole process is a not tender but forceful and a squeeze is maintained as not to allow the channeled blood to escape the forward thrust. Once the bad blood is in the hand, forceful massage and squeezing occurs to get the blood to the thumb. This is strong enough to make the thumb turn purple. At this time a sewing needle that has been sterilized by the flame of a match stick is used to pick the skin to remove the channeled bad blood. About a one milliliter of blood is removed by this process. Well, the only harm I could see now on the kids is a small wound on their thumb that has clotted over well and on its way to recovery. In my scientist-colored glasses I am thinking it is a good thing the kids are not hemophiliacs as they would be bruised and probably still be bleeding the bad blood out.

After obtaining the full description of the procedure I see the kids were kind of mystified by it all and now started the chant dad's turn, dad's turn. Grandma lights the match and suggesting that I lie down. Against all better judgment I go along with it to keep the family peace. After a few days all of us are finished with our stomach aches and are feeling better. Grandma points to the thumb and says better. all gone. Just like you, the reader, I had to ask the question, What would happen if we did not get the bad blood out? Through translation the answer came back that we would have been sick longer.

One can expect some strange practices in
Correspondence: Robin L. Cooper, Department of Biology, BSN student in College of Nursing, University of Kentucky 675 Rose Street, Lexington, KY, USA.

Fax: +1.859.257.1717.

E-mail: RLC00P1@email.uky.edu

Key words: transcultural.

Received for publication: 16 September 2011. Accepted for publication: 20 September 2011.

This work is licensed under a Creative Commons Attribution 3.0 License (by-nc 3.0).

(C) Copyright R.L. Cooper, 2011

Licensee PAGEPress, Italy

Nursing Reports 2011; 1:e6

doi:10.4081/nursrep.2011.e6

the clinics but I never really thought it would happen in my own home. So if you hear of Korean bloodletting with your patients look at the thumbs for signs and symptoms of infection 24 to $48 \mathrm{~h}$ later and hope they do not have a blood clotting disorder or bruise easily.

Well such an experience struck an interest in knowing more about other health care differences from the ancient culture of Korea, so please forward any reports or nuances to me.

\section{References}

1. Payton, B. History of medicinal leeching and early medical references. In: Muller KJ, Nicholls JG, Stent GS, eds. Neurobiology of the leech. Cold Springs Harbor, NY: Cold Springs Harbor Laboratory; 1981. pp. 27-34.

2. Whitaker IS, Josty IC, Hawkins S, et al. Medicinal leeches and the microsurgeon: a four-year study, clinical series and risk benefit review. Microsurgery 2011;31:2817. 